\title{
The Contribution of Sonoelastography to the Diagnosis and Correlation of Strain Index Values with Pathological Subgroups in Fibroepithelial Breast Lesions
}

\author{
Fibroepitelyal Meme Lezyonlarında Sonoelastografinin Tanıya Katkısı ve Patolojik Alt \\ Gruplar ile Strain İndeks Değerlerinin Korelasyonu
}

\author{
(D) Fatma Can11, (D) Kevser Esmeray Çifci2, (1) Mehmet Ali Nazlı3 \\ ${ }^{1}$ Katip Çelebi University, Atatürk Training and Research Hospital, Clinic of Radiology, İzmir, Turkey \\ 2Darıca Farabi Training and Research Hospital, Clinic of Radiology, Kocaeli, Turkey \\ 3University of Health Sciences Turkey, Bașakșehir Çam ve Sakura City Hospital, Clinic of Radiology, İstanbul, Turkey
}

\begin{abstract}
Introduction: Fibroepithelial lesions are the most common benign lesions of the breast. When detected by mammography and ultrasonography (USG), the limitations of these examinations and the goal of diagnosing malignant lesions at an early stage may lead to off-label biopsies. Unnecessary biopsy procedures can be avoided by developing additional reliable methods to complement existing diagnostic procedures. For more accurate characterization of breast lesions, US elastography is used, which gives information about elasticity and deformability of the tissue. In our study, we aimed to determine the contribution of elastography to the diagnosis in the evaluation of fibroepithelial lesions of the breast with USG and to determine the relationship between strain index (SI) values and pathological subgroups.
\end{abstract}

Methods: Our study included 160 lesions in 105 patients who were diagnosed with pathologically proven fibroepithelial lesion in the Radiology Clinic of istanbul Training and Research Hospital between September 2013 and November 2014, or who were followed up for at least two years with no pathology and whose radiological appearance was interpreted in favor of fibroadenoma (FA). Voluntary consent form and ethics committee approval for the study were obtained from the patients. USG examinations were performed with a 13-18 $\mathrm{MHz}$ linear high resolution volumetric probe. Considering the color map obtained in the elastography evaluation, different measurements were made from the hardest areas in the mass.

Results: In the sonoelastographic evaluation of fibroepithelial lesions, the median mean $\mathrm{SI}$ value was calculated as 3.30 (between: 0.35 and 28.80). The SI value was found to be higher in complex FAs than in other subgroups. It was observed that the mean size decreased as the age group got older. A statistically significant positive correlation was found between elastography stiffness index and size $(p<0.0001$, Pearson correlation index 0.643).

\section{öz}

Amaç: Fibroepitelyal lezyonlar memenin en sık görülen benign lezyonlarıdır. Mamografi ve ultrasonografi (USG) ile saptandığında, bu tetkiklerin sınırlamaları ve malign lezyonlara erken evrede tanı koyma hedefi endikasyon dıșı biyopsilere yol açabilmektedir. Mevcut tanı prosedürlerini tamamlayacak ek güvenilir yöntemlerin geliştirilmesiyle gereksiz biyopsi işlemleri önlenebilir. Meme lezyonlarının daha doğru karakterize edilebilmesi için, elastisite ve dokunun deformabilitesi hakkında bilgi veren US elastografi kullanıımaktadır. Çalışmamızda memenin fibroepitelyal lezyonlarının USG ile değerlendirilmesinde elastografinin tanıya katkısını ve strain indeks (Si) değerlerinin patolojik alt gruplarla ilişkisini belirlemeyi amaçladık.

Yöntemler: Çalıșmamıza İstanbul Eğitim ve Araștırma Hastanesi, Radyoloji Kliniği'nde Eylül 2013-Kasım 2014 tarihleri arasında patolojik olarak kanıtlanmış fibroepitelyal lezyon tanılı veya patolojisi olmamakla birlikte en az iki yıl takipli, radyolojik görünümü fibroadenom (FA) lehine yorumlanmış 105 hastada 160 lezyon dahil edildi. Hastalardan gönüllü onam formu ve çalışma için etik kurulu onayı alındı. USG incelemeler 13-18 $\mathrm{MHz}$ lineer yüksek rezolüsyonlu volümetrik prob ile gerçekleştirildi. Elastografi değerlendirmede elde edilen renkli harita göz önünde bulundurularak, kitle içerisinde en sert alanlardan farklı ölçümler yapıımıştır.

Bulgular: Fibroepitelial lezyonların sonoelastografik değerlendirmesinde medyan ortalama Si değeri 3,30 (arasında: 0,35 ve 28,80 ) olarak hesaplanmıştır. Kompleks FA'larda Si değeri diğer alt gruplardan yüksek bulunmuştur. Yaş grubu büyüdükçe boyut ortalamasının azaldığı görülmüștür. Elastografi sertlik indeksi ile boyut arasında istatistiksel olarak anlamlı pozitif yönde bir korelasyon saptanmıştır $(p<0,0001$, Pearson korelasyon indeksi 0,643).
Address for Correspondence/Yazıșma Adresi: Kevser Esmeray Çifci MD, Darıca Farabi Training and Research Hospital Clinic of Radiology, Kocaeli, Turkey

Phone: +90 5053241139 E-mail: kevser.esmeray@yahoo.com ORCID ID: orcid.org/orcid.org/0000-0002-8518-7390

Cite this article as/Atıf: Can F, Çifci KE, Nazlı MA. The Contribution of Sonoelastography to the Diagnosis and Correlation of Strain Index Values with Pathological Subgroups in Fibroepithelial Breast Lesions. İstanbul Med J 2021; 22(4): 306-12.

(c) Copyright 2021 by the University of Health Sciences Turkey, Istanbul Training and Research Hospital/istanbul Medical Journal published by Galenos Publishing House

(C) Telif Hakkı 2021 Sağıı Bilimleri Üniversitesi Istanbul Ĕgitim ve Araştırma Hastanesi/Istanbul Tıp Dergisi, Galenos Yayınevi tarafından basılmıștır.
Received/Geliș Tarihi: 02.08.2021 Accepted/Kabul Tarihi: 12.10 .2021 
Conclusion: We think that US elastography contributes to morphological USG findings in the evaluation of fibroepithelial lesions of the breast and can guide the biopsy decision correctly. Keywords: Ultrasonography, US elastography, fibroepithelial lesion, fibroadenoma
Sonuç: Memenin fibroepitelial lezyonlarının değerlendirilmesinde US elastografinin morfolojik USG bulgularına katkı sağladığı, biyopsi kararında doğru yönlendirme yapabileceğini düşünmekteyiz.

Anahtar Kelimeler: Ultrasonografi, US elastografi, fibroepitelyal lezyon, fibroadenom

\section{Introduction}

Fibroepithelial lesions of the breast describe a biphasic and heterogeneous group of neoplasms that range from benign to malignant, characterized by varying degrees of stromal proliferation associated with the epithelial compartment. We frequently see these lesions in the clinic (1).

Fibroadenomas (FA) are the most common solid benign lesions consisting of balanced biphasic proliferation of glandular and stromal elements. FAs accompanied by epithelial component changes are called complex FAs (1,2). FAs can be safely followed without further research (3).

Phyllodes tumor is similar to FA, but has more cellularity in its stroma, and its typical feature is the presence of malignant potential, despite its benign character. Phyllodes tumors can be classified as benign lesions or borderline and high-grade malignancies according to pathological findings (1). Fibroadenolipoma, on the other hand, is a rare benign tumor consisting of well-limited, encapsulated, fatty, fibrous and adenomatous elements (4). Phyllodes tumors can be benign or malignant. Clinically, it is usually a hard round tumor. The fact that the tumor is very large or its rapid growth also indicates a phyllodes tumor, rather than FA. In patients with very large phyllodes tumors, ulceration of the skin or invasion of the chest wall may occur (3).

The limitations of mammography (MG) and ultrasonography (USG) and the goal of diagnosing malignant lesions at an early stage may lead to off-label biopsies. The cancer detection rate of biopsies is between 10$30 \%$. Unnecessary biopsy procedures increase the cost, disrupt patient comfort and cause anxiety. Unnecessary biopsy procedures can be avoided by developing additional reliable methods to complement existing diagnostic procedures (5).

In order to characterize breast lesions more accurately, the US elastography technique, which provides information about elasticity and deformability of the tissue, has been put into use. In this technique, the basic principles of USG technology and elastography are combined (6). Malignant tissues are generally found to be tougher than benign tissues due to the common desmoplastic reactions they contain, therefore they are observed as less elastic in sonoelastographic examinations (7).

Currently, the most preferred method in the clinical setting is realtime elastography (RTE), which provides "strain imaging" by means of compression. RTE can be performed with conventional USG equipment with related software, and in this method, an elastogram is created on the USG image and updated in real time at a frequency of $10-15 \mathrm{~Hz}$ to evaluate the relative elasticity of tissues in a specific target region.

The elastogram, which reflects the relative elasticity of the tissues, is displayed by color coding (high stiffness areas in blue, more deformable areas in red, and moderately elastic areas in green). The lighter shades of the base color represent different degrees of tissue deformability and correlate with the dynamic range of the analytical system.

Some researchers have suggested the use of "strain ratio" or "strain index (SI)" in order to minimize the differences between operators in the differentiation of malignant and benign lesions. Calculation of the strain ratio is based on determining the mean strain value measured in the lesion and comparing it with the mean strain value of a similar adipose tissue in the adjacent breast tissue. The strain ratio reflects the relative hardness of the lesion.

In some studies, it has been found that the mean SI of malignant lesions is higher than that of benign lesions (6).

In this retrospective study, we aimed to determine the contribution of elastography and SI values to the diagnosis in the evaluation of fibroepithelial lesions of the breast with USG and their correlation with histopathological subtypes.

\section{Methods}

Our study included 105 patients with a diagnosis of pathologically proven fibroepithelial lesion, 88 (55\%) with at least two years of followup, and their radiological appearance interpreted in favor of FA, between September 2013 and November 2014 at the İstanbul Training and Research Hospital, Clinic of Radiology. One hundred and sixty lesions were included in the patient. Voluntary consent form were obtained from the patients. The approval form the University of Health Sciences Turkey, İstanbul Training and Research Hospital Local Ethics Committee was obtained (approval number: 550, date: 28.11.2014).

\section{Patient Selection}

According to the morphology, echo structure, size, long-short axis relationship, lesion borders, and orientation to the chest wall of the lesion in the axial and sagittal planes in the USG evaluation, it was interpreted in favor of FA; female patients over the age of 18 with lesions that resulted as fibroepithelial lesion as a result of pathology and were followed up for at least two years were included in the study.

\section{Ultrasonographic B-mode and Elastography Evaluation}

Ultrasonographic examinations were performed with a 13-18 $\mathrm{MHz}$ linear high resolution volumetric probe (Toshiba Aplio 400, Japan, 2014). Imaging and measurements were made by a single practitioner with 10 years of experience in breast radiology.

\section{USG Technique}

In the examination, all quadrants of the breast were scanned in different planes. Parameters such as the largest diameters of the fibroepithelial 
lesions, shape and contour features, and internal echo structures were included in the study.

\section{Elastography Technique}

Following conventional USG, US elastography assessment was performed by applying repetitive compressions at one-second intervals, at constant power, on the mass. Images with the same morphology and wave spectrum at least 5 times were analyzed. Considering the color map obtained, different measurements were made from the hardest areas in the mass. Care was taken to ensure that the measurements did not include cystic and calcified areas. SI measurements were made with post processing elastography during the examination and real time elastography in those performed after June 2014. SI was calculated by placing the first region-of-interest (ROI) on the target lesion and the second ROI on the lateral subcutaneous adipose tissue at the same size and depth as the target lesion.

\section{Statistical Analysis}

Descriptive statistics were presented as mean, standard deviation, and percentage. The mean of the two groups was compared with the t-test for independent groups. The mean of more than two groups was compared with One-Way ANOVA comparison methods. The distribution of categorical features relative to each other and the comparison of sonographic and elastographic parameters of Fibroepithelial lesions according to histopathological diagnosis were made using the chisquare test. The significance level was accepted as 0.05 in all tests.

\section{Results}

One hundred and sixty lesions in 105 female patients were included in the study. The ages of the patients were between 18-75 and the mean age was calculated as $40,13.23,1 \%$ of the patients were under 30 years old, $58.1 \%$ were between $30-48$ years old and $18.8 \%$ were over 50 years old.

The side distribution of the lesions is given in Table 1, and the localization distribution is given in Chart 1. The mean lesion size of 160 cases was $15.98 \pm 9.47 \mathrm{~mm}(3.50-84.0 \mathrm{~mm})$ and the mean SI of 159 cases was calculated as $5.30 \pm 4.97(0.35-28.80)$.

In the sonoelastographic evaluation of the lesions; SI values obtained were between 0.35 and 28.80 (mean SI: 4.97). The median SI value was found to be 3.30. SI value could not be measured in the patient with borderline phyllodes tumor because the mass almost completely filled the breast.

When $\mathrm{SI}$ values were considered to be 5 for the malignant-benign distinction, $75.5 \%(n=120)$ were found to be below 5 and $24.5 \%(n=39)$ were found to be above 5 when an immeasurable lesion was ruled out in our cases.

\begin{tabular}{|l|l|}
\hline Table 1. Side distribution of lesions \\
\hline Side distribution & Number of lesions \\
\hline Right breast & $84(52.5 \%)$ \\
\hline Left breast & $76(47.5 \%)$ \\
\hline Total & 160 \\
\hline
\end{tabular}

The distribution of the lesions according to their shape characteristics is given in Table 2. When Pearson chi-square test was used to evaluate the correlation between lesion shape features and SI values, the p-value was found to be 0.046 , and the SI of lobular lesions was significantly lower than lesions with other morphology (Figure 1). When the lesions are classified according to their shapes, the lobular lesion with an SI below 5 is the most common (79.8\%), and the least group with an SI below 5 is the spherical group.

When the lesions are evaluated according to their internal echoes, they are mostly homogeneous (80\%) lesions with an SI below 5 . When the Pearson chi-square test was used, the $p$-value was found to be 0.745 , and there was no significant relationship between internal echo and SI. The distribution of internal echo characteristics according to USG is shown in Chart 2.

Using the One-Way anova test, a significant inverse relationship was found between the age groups of the patients and the size of the lesion $(p=0.001)$. It was observed that the mean size decreased as the age group got older (Table 3 ). However, no significant correlation was found between $\mathrm{SI}$ and patient age $(\mathrm{p}=0.185)$.

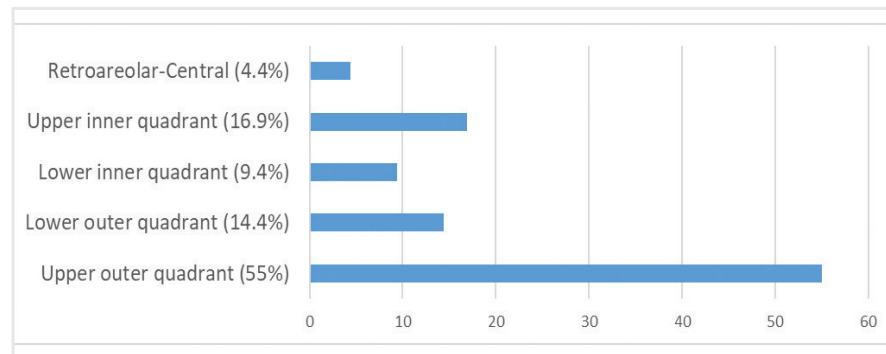

Chart 1. Distribution of lesion localizations



Chart 2. Distribution of internal echo characteristics according to ultrasonography

Table 2. The distribution of lesions according to their shape characteristics

\begin{tabular}{l|l} 
Round (5\%) & 8
\end{tabular}

\begin{tabular}{l|l} 
Oval (41.9\%) & 67
\end{tabular}

\begin{tabular}{l|l} 
Lobule (52.5\%) & 84
\end{tabular}

Irregular (0.6\%) 
A statistically significant positive correlation was found between elastography stiffness index and size $(p<0.0001$, Pearson correlation index 0.643).

Percentage distribution of pathological subgroups is shown in Chart 3. When the mean SI values of the pathological subgroups were examined, the highest SI value and the largest dimension were found in complex FA (Figure 2). The highest mean age in lesions diagnosed with FA was found in degenerated FA (Table 4).
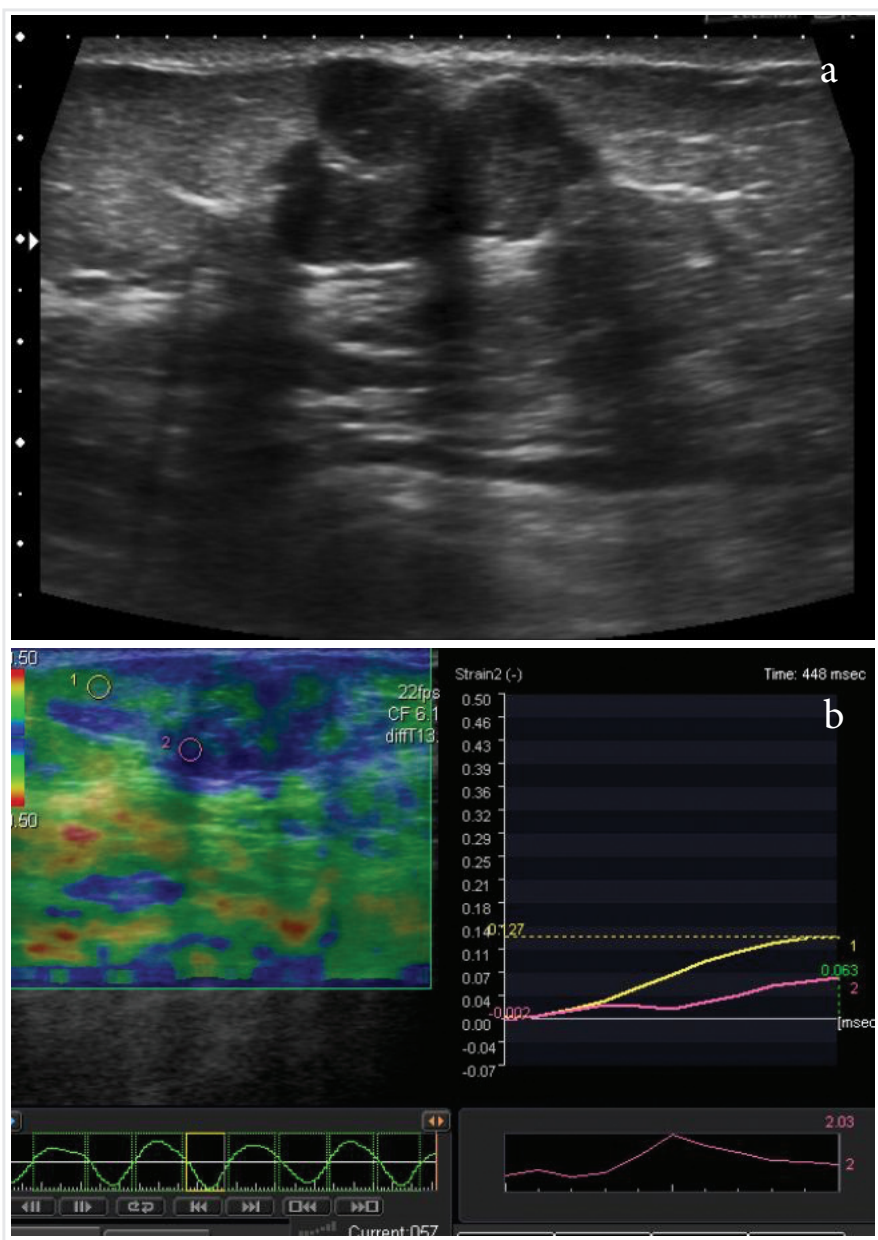

Figure 1. A 32-year-old patient with histopathological diagnosis of FA; a) hypoechoic solid lesion with lobulated contour and echogenic internal septation on B mode US image; b) It is seen that the SI value (2.03) is low in US elastography

FA: Fibroadenomas, US: UItrasound, SI: Strain index

Table 3. Distribution of strain index values and sizes of lesions by age groups

\begin{tabular}{|l|l|l|l|}
\hline Age groups & & $\mathbf{n}$ & Mean \pm SD \\
\hline \multirow{3}{*}{ Size } & $<30$ age & 37 & $20.7 \pm 14.3$ \\
\hline & $30-49$ age & 93 & $15.1 \pm 7.0$ \\
\hline & $>=50$ age & 30 & $12.7 \pm 6.1$ \\
\hline \multirow{3}{*}{ Strain index } & $<30$ age & 36 & $4.0 \pm 5.3$ \\
\hline & $30-49$ age & 93 & $4.8 \pm 4.9$ \\
\hline & $>=50$ age & 30 & $6.4 \pm 6.2$ \\
\hline
\end{tabular}

SD: Standard deviation

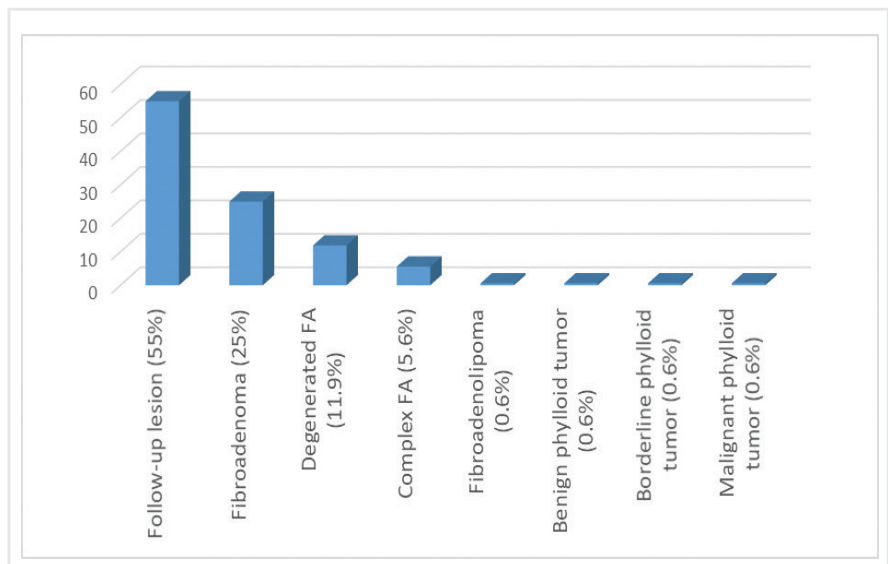

Chart 3. Distribution of pathological subgroups
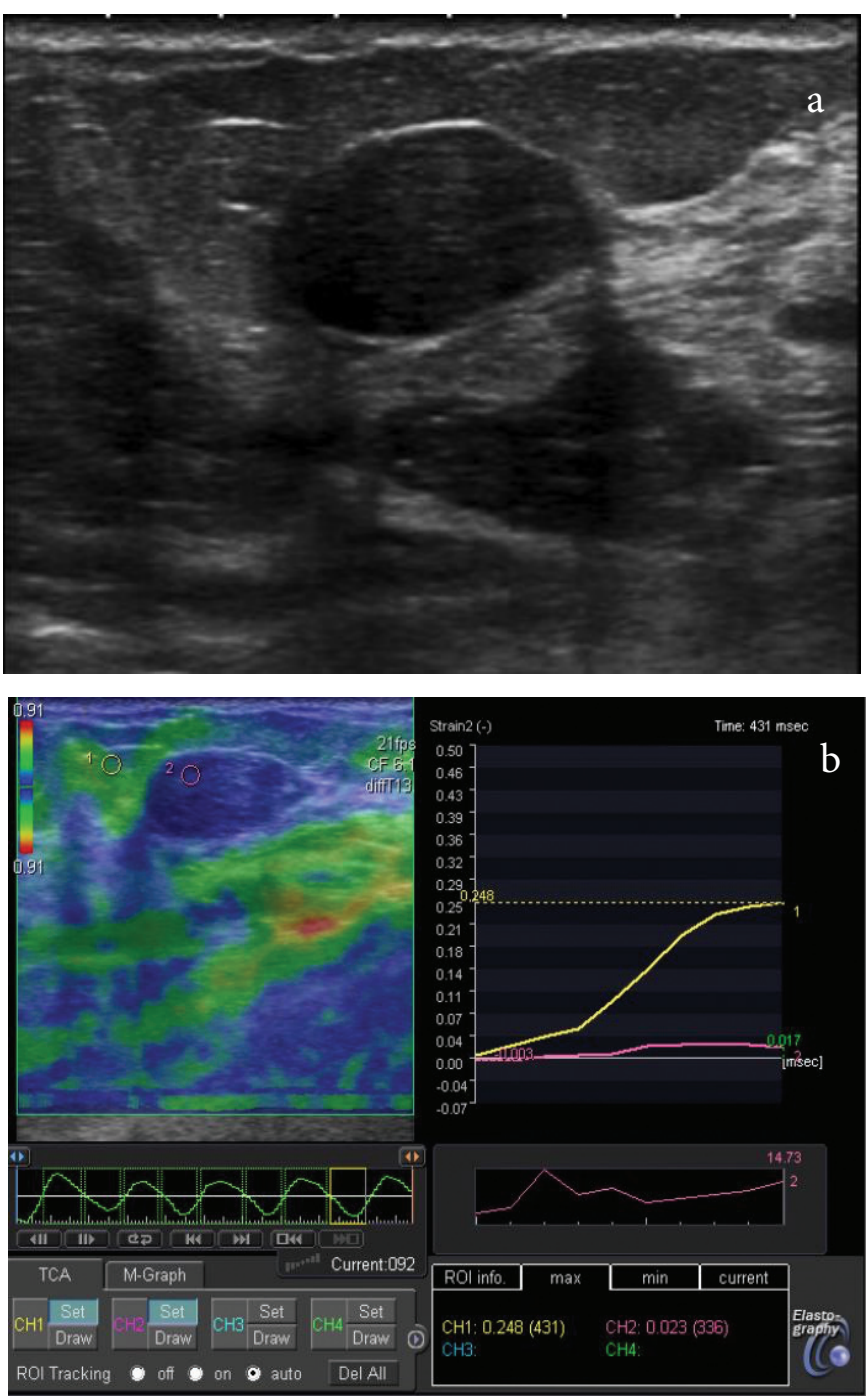

Figure 2. A 37-year-old patient with histopathological diagnosis of complex FA; a) oval shaped, hypoechoic-homogeneous lesion on B mode US image; b) the SI value (14.73) was found to be significantly higher in US elastography

FA: Fibroadenomas, US: Ultrasound, SI: Strain index 


\begin{tabular}{|c|c|c|c|}
\hline Pathological subgroup & \multirow{2}{*}{$\begin{array}{l}\text { Age } \\
40\end{array}$} & \multirow{2}{*}{$\begin{array}{l}\text { Strain index } \\
40\end{array}$} & \multirow{2}{*}{$\begin{array}{l}\text { Size }(\mathrm{mm}) \\
40\end{array}$} \\
\hline Number & & & \\
\hline Number & 9 & 9 & 9 \\
\hline Mean \pm SD & $36.78 \pm 8.96$ & $7.56 \pm 6.91$ & $22.78 \pm 14.57$ \\
\hline Number & 1 & 1 & 1 \\
\hline Mean \pm SD & 39 & 4.55 & 3.5 \\
\hline Number & 1 & - & 1 \\
\hline Mean \pm SD & 27 & - & 84 \\
\hline Mean \pm SD & $39.38 \pm 13.76$ & $4.07 \pm 3.64$ & $13.26 \pm 5.05$ \\
\hline Number & 1 & 1 & 1 \\
\hline Mean \pm SD & 51 & 4.87 & 38 \\
\hline
\end{tabular}

\section{Discussion}

FA are common benign lesions of the breast and are usually detected as a solitary breast mass in young women $(1,2,8)$. FAs are benign fibroepithelial tumors and consist of epithelial and stromal layers. Multiple FAs are present in 15\% of the cases (1). In the literature, FAs were detected most frequently in the upper outer quadrant, and in our study, $55 \%$ of the lesions were in this localization $(9,10)$.

Phyllodes tumor of the breast is a rare fibroepithelial breast tumor that accounts for less than $1 \%$ of all primary breast neoplasms and 2-3\% of all fibroepithelial tumors. Phyllodes tumors are usually seen in women between the ages of 35-55. Although similar to benign FAs, they are distinguished from FAs by histologically increased cellularity and clinically by local recurrence and metastatic spread. According to the classification of the World Health Organization, there are 3 types of phyllodes tumors: benign, borderline and malignant. High-grade malignant phyllodes constitute approximately $25 \%$ of all phyllodes (11).

The entire spectrum of benign and malignant epithelial changes can be seen in complex FAs. While benign processes such as lactational changes, simple cysts, apocrine metaplasia, and sclerosing adenosis may occur, atypia ductal or lobular hyperplasia, ductal or lobular in situ carcinomas and even invasive carcinomas may develop within FA or may develop in the adjacent parenchyma and invade the FA tissue secondarily (1).

In a study where they compared complex FAs with simple FAs, SklairLevy et al. (2) reported that complex FAs were more common in elderly patients and were smaller in size. In our study, the highest SI value and the highest mean size were observed in complex FAs in lesions diagnosed with FA. The highest mean age was obtained in degenerated FAs.

Our study showed that increasing lesion diameter of fibroepithelial lesions caused an increase in SI values indicating the degree of tissue stiffness, and this finding is consistent with the study of
Elseedawy et al. (12) evaluated 151 fibroadenoma cases with shear wave elastography and showed that the main determinant of fibroadenoma stiffness was the size of the lesion. The reason for these findings was accepted as more compression of the adjacent normal tissue (12). In addition, in parallel with our findings, in a multicenter study conducted with 1,562 cases, it was shown that the stiffness of FA and malignant tumors was correlated with increasing lesion size, but there was no correlation between size and stiffness in other solid and cystic lesions of the breast (13).

In the study of Chao et al. (14) with 110 patients with phyllodes tumors and 2204 with FA, the most common morphology of FAs was reported to be round and oval, while phyllodes tumors were reported to be lobulated (14). However, in our study, the most common form of mass in both FA and phyllodes tumors was lobulated. The same study classified the lesions as homogeneous and heterogeneous according to their internal echoes. 1907 (86.5\%) of FAs were homogeneous, 298 (13.5\%) were heterogeneous; 39 (35.4\%) of phyllodes tumors were reported as homogeneous and $71(64.6 \%)$ as heterogeneous (14). Similar to the study of Chao et al. (14), the most common internal echo pattern was homogeneous in our study.

In recent years, elastography has been increasingly used in the evaluation of soft tissue lesions. In studies conducted in recent years, the sensitivity of elastography in the differentiation of benign and malignant breast lesions was 78-100\%; and its specificity is reported as 21-99\% (15).

Zhi et al. (16), in their study including 559 solid lesions, found the mean SI value of benign lesions as 1.8 and the mean SI value of malignant lesions as 8.42. FA, fibrocystic mastopathy and invasive ductal cancer constitute the majority of lesions in this study. The mean SI value of FAs was found to be 1.79 (16). In our study, this value was obtained as a mean SI value of 4.97 and a median SI value of 3.30 for fibroepithelial lesions, the majority of which consisted of FA (16). 
Similarly, Burnside et al. (17) found that strain US elastography increases the sensitivity and specificity rate in diagnosis, but US elastography experience among radiologists significantly affects these rates.

The SI values of 79 benign lesions included in the study of Cho et al. (18) ranged from 0.54 to 38.76, with a mean SI value of 2.63. In this study, it was shown that sonoelastography and SI are useful in distinguishing between benign and malignant lesions, and it has been reported that they are beneficial in reducing the number of unnecessary biopsies (18).

In the study of Kim et al. (19), it was reported that sonoelastographic evaluation is most useful in the differentiation of benign-malignant breast lesions with complex echogenicity.

In recent studies, the efficiency of shear wave elastography and strain elastography has been compared with simultaneous applications. In these studies, it was shown that adding strain or shear wave elastography to B mode US findings improves diagnostic performance and these elastography techniques have similar diagnostic performance $(20,21)$. In the study of Fujioka et al. (20), it was reported that the use of elastography in combination with B-mode US may be helpful in avoiding unnecessary biopsies in patients with BI-RADS category 4a masses.

\section{Study Limitations}

Lesions with radiological imaging findings suggestive of typical FA, followed for more than two years, and did not increase in size during follow-up did not have a histopathological diagnosis. In addition, since the data were evaluated retrospectively, the patients could not be differentiated as pre-peri-postmenopausal period, instead they were evaluated in different groups in terms of age. Since the number of our patients with phyllodes tumor is significantly low, the predictive value of the values obtained in this regard is limited.

\section{Conclusion}

Fibroepithelial lesions are breast lesions mostly consisting of FAs, which are common benign masses of the breast, and are frequently seen in young age. In the diagnosis, the diagnosis can usually be made correctly with the findings defined by classical B mode USG and follow-up is applied.

In the premenopausal period, biopsy is not required except for those who are larger than $2 \mathrm{~cm}$ in size and increase in size. After the age of 30 , there are difficulties in diagnosis, especially in the perimenopausal period, unnecessary biopsies are performed, and more importantly, malignant lesions are interpreted as FA and malignancies can be missed, and delays in diagnosis and treatment may occur.

We think that US Elastography will contribute to the morphological USG findings in the evaluation of FAs and can guide the biopsy decision correctly. However, biopsy indications of newly developed solid lesions, especially in the postmenopausal period, cannot be eliminated by US elastography.

Ethics Committee Approval: The approval form the University of Health Sciences Turkey, İstanbul Training and Research Hospital Local Ethics Committee was obtained (approval number: 550, date: 28.11.2014).
Informed Consent: Voluntary consent form were obtained from the patients.

Peer-review: Externally peer-reviewed.

Authorship Contributions: Surgical and Medical Practices - F.C., K.E.Ç., M.A.N.; Concept - F.C., M.A.N.; Design - F.C., M.A.N.; Data Collection or Processing - F.C., K.E.C.; Analysis or Interpretation - M.A.N.; Literature Search - F.C., K.E.C.; Writing - F.C., K.E.C.

Conflict of Interest: No conflict of interest was declared by the authors.

Financial Disclosure: The authors declared that this study received no financial support.

\section{References}

1. Tan BY, Tan PH. A diagnostic approach to fibroepithelial breast lesions. Surg Pathol Clin 2018; 11: 17-42.

2. Sklair-Levy M, Sella T, Alweiss T, Craciun I, Libson E, Mally B. Incidence and management of complex fibroadenomas disclosures. Am J Roentgenol 2008; 190: $214-8$

3. Wiratkapun C, Piyapan P, Lertsithichai P, Larbcharoensub N. Fibroadenoma versus phyllodes tumor: distinguishing factors in patients diagnosed with fibroepithelial lesions after a core needle biopsy. Diagn Interv Radiol 2014; 20: 27-33.

4. Rosen MA, Siegelmen ES. MRI of the Breast. In: Siegelmen ES, (editor) Philadelphia, Elsevier; 2004: p. 425-79.

5. Zhi H, Ou B, Luo BM, Feng X, Wen YL, Yang HY. Comparison of ultrasound elastography, mammography, and sonography in the diagnosis of solid breast lesions. J Ultrasound Med 2007; 26: 807-15.

6. Goddi A, Bonardi M, Alessi S. Breast elastography: A literature review. J Ultrasound 2012; 15: 192-8.

7. Yerli H, Yılmaz T, Ural B, Gülay H. The diagnostic importance of evaluation of solid breast masses by sonoelastography. Ulusal Cer Derg 2013; 29: 67-71.

8. Thakur B, Misra V. Clinicohistopathological features of fibroadenoma breast in patients less than 20 years of age and its comparison with elder patients. IOSR Journal of Nursing and Health Science 2014; 3: 67-71.

9. Chung EM, Cube R, Hall GJ, González C, Stocker JT. From the archives of the AFIP: breast masses in children and adolescents: radiologic-pathologic correlation. Radiographics 2009; 29: 907-31.

10. Greenberg R, Skornick Y, Kaplan O. Management of breast fibroadenomas. J Gen Intern Med 1998; 13: 640-5.

11. Cabıoğlu N, Çelik T, Özmen V, Ĭği A, Müslümanoğlu M, Özçınar B, et al. Treatment modalities of phyllodes tumors of the breast. J Breast Health 2008; 4: 99-104.

12. Elseedawy M, Whelehan P, Vinnicombe S, Thomson K, Evans A, et al. Factors influencing the stiffness of fibroadenomas at shear wave elastography. Clin Radiol 2016; 71: 92-5.

13. Berg WA, Mendelson EB, Cosgrove DO, Doré CJ, Gay J, Henry JP, et al. Quantitative Maximum Shear-Wave Stiffness of Breast Masses as a Predictor of Histopathologic Severity. AJR Am J Roentgenol 2015; 205: 448-55.

14. Chao TC, Lo YF, Chen SC, Chen MF. Sonographic features of phyllodes tumors of the breast. Ultrasound Obstet Gynecol 2002; 20: 64-71.

15. Cho N, Moon WK, Park JS, Cha JH, Jang M, Seong MH. Nonpalpable breast masses: evaluation by US elastography. Korean J Radiol 2008; 9: 111-8. 
16. Zhi H, Xiao XY, Yang HY, Ou B, Wen YL, Luo BM. Ultrasonic elastography in breast cancer diagnosis: strain ratio vs 5-point scale. Acad Radiol 2010; 17 : 1227-33.

17. Burnside ES, Hall TJ, Sommer AM, Hesley GK, Sisney GA, Svensson WE, et al. Differentiating benign from malignant solid breast masses with US strain imaging. Radiology 2007; 245: 401-10.

18. Cho N, Moon WK, Kim HY, Chang JM, Park SH, Lyou CY. Sonoelastographic strain index for differentiation of benign and malignant non-palpable breast masses. J Ultrasound Med 2010; 29: 1-7.

19. Kim MY, Cho N, Yi A, Koo HR, Yun BL, Moon WK. Sonoelastography in distinguishing benign from malignant complex breast mass and making the decision to biopsy. Korean J Radiol 2013; 14: 559-67.
20. Fujioka T, Mori M, Kubota K, Kikuchi Y, Katsuta L, et al. Simultaneous comparison between strain and shear wave elastography of breast masses for the differentiation of benign and malignant lesions by qualitative and quantitative assessments. Breast Cancer 2019; 26: 792-8.

21. Seo M, Ahn HS, Park SH, Lee JB, Choi BI, Sohn YM, et al. Comparison and combination of strain and shear wave elastography of breast masses for differentiation of benign and malignant lesions by quantitative assessment: preliminary study. J Ultrasound Med 2018; 37: 99-109. 